\title{
Author Correction: Metabolic engineering of Saccharomyces cerevisiae for production of very long chain fatty acid-derived chemicals
}

Tao Yu, Yongjin J. Zhou, Leonie Wenning, Quanli Liu, Anastasia Krivoruchko, Verena Siewers, Jens Nielsen \& Florian David

Nature Communications 8:15587 doi: 10.1038/ncomms15587 (2017); Published 26 May 2017, Updated 13 Jul 2018

In the originally published version of this Article, financial support was not fully acknowledged. The PDF and HTML versions of the Article have now been corrected to include support from the European Union's Horizon 2020 Framework Programme for Research and Innovation-Grant Agreement No. 720824.

(c) Open Access This article is licensed under a Creative Commons Attribution 4.0 International License, which permits use, sharing, adaptation, distribution and reproduction in any medium or format, as long as you give appropriate credit to the original author(s) and the source, provide a link to the Creative Commons license, and indicate if changes were made. The images or other third party material in this article are included in the article's Creative Commons license, unless indicated otherwise in a credit line to the material. If material is not included in the article's Creative Commons license and your intended use is not permitted by statutory regulation or exceeds the permitted use, you will need to obtain permission directly from the copyright holder. To view a copy of this license, visit http://creativecommons.org/licenses/by/4.0/

(C) The Author(s) 2018 